\title{
Study of individual plant responsiveness in anther cultures of selected pepper (Capsicum spp.) genotypes
}

\author{
Aleksandra Niklas-Nowak*, Dorota Olszewska, Anna Kisiata, Pawel Nowaczyk \\ Department of Genetics and Plant Biotechnology \\ University of Technology and Life Sciences \\ Prof. S. Kaliskiego 7, 85-789 Bydgoszcz, Poland
}

\begin{abstract}
One of the key factors determining the effectiveness of pepper anther cultures is donor plant genotype. The stock material for androgenic embryos inductions is usually made up of hybrid forms, since the higher the degree of heterozygosity, the greater the chances of producing regenerates with unique genotypes. The aim of the presented research was to evaluate individual plant reaction in anther cultures for the $C$. annuum hybrid ('ATZ1' $\times$ ' $\left.\mathrm{TG}^{\prime}\right) \mathrm{F}_{2}$, interspecific hybrid $(C$. frutescens $\times C$. chinense $) \mathrm{F}_{2}$ and androgenic $\mathrm{DH}$ line AT6. The effectiveness of androgenesis was determined individually for each plant as the percentage of the embryos produced compared to the total number of anthers cultured. In the hybrid ('ATZ1' $\times$ ' $\mathrm{TG}$ ')F $\mathrm{F}_{2}$, anthers of 19 out of 20 plants evaluated produced embryos at a rate of 0.5 to $16.5 \%$. Anthers of the AT6 DH line formed embryos considerably less frequently. A positive reaction was recorded for 13 out of 20 plants and the effectiveness of androgenesis did not exceed 3\% for this genotype. The lowest androgenic response was recorded for the hybrid $(C$. frutescens $\times C$. chinense $) \mathrm{F}_{2}$, where embryo development was observed in only five out of 19 plants and the effectiveness of androgenesis did not exceed $2 \%$. The ploidy level of the regenerates was defined cytometrically. The analysis revealed the presence of haploid and diploid plants among the regenerates of all the genotypes evaluated.
\end{abstract}

Key words: androgenesis, DH line, donor plant genotype, haploid, hybrid

\section{INTRODUCTION}

Both local and international research into induced androgenesis of pepper concern mostly the domesticated species of $C$. annuum (Ercan et al. 2006, Nowaczyk and Kisiała 2006, Supena et al. 2006, Kim et al. 2008), while the applicable literature provides much less information on wild species and interspecific hybrids representing the Capsicum genus (Mityko et al. 1995, Nowaczyk et al. 2006, Niklas-Nowak and Nowaczyk 2009). The earlier research results point to the fact that the effectiveness of androgenesis depends on many factors, including species, microspore developmental stage, composition of media and in vitro culture conditions (Özkum Çıner and Tipirdamaz 2002, Kim et al. 2008, Niklas-Nowak and Nowaczyk 2009, Lantos et al. 2012). However, the crucial factor determining the effectiveness of androgenesis for many species, including pepper, is clearly the genotype of anther donor plants (Kristiansen and Andersen 1993, Nowaczyk et al. 2009b). The stock material for the induction of embryos most frequently consists of hybrid 
forms, both $F_{1}$ and $F_{2}$ generations (Choo 1981, Nowaczyk et al. 2009b). The research determined that the higher the degree of heterozygosity of the maternal plants used for the induction of haploids, the greater the chances of producing forms with the unique genotype that can provide valuable breeding material. Choo (1981) confirmed that among the androgenic regenerates of the $\mathrm{F}_{2}$ hybrid generation, even $50 \%$ more favourable recombinants can occur, as compared to the doubled haploid population produced from the $F_{1}$ hybrid generation, especially when accompanied by gene linkage.

The aim of the present research was to evaluate the response of individual plants of two pepper $\mathrm{F}_{2}$ hybrid forms and the $\mathrm{DH}$ line derived from the intraspecific $\mathrm{F}_{1}$ hybrid for the conditions of in vitro anther cultures.

\section{MATERIAL AND METHODS}

The research material consisted of $\mathrm{F}_{2}$ generations of the hybrid between cultivated lines of $C$. annuum L. 'ATZ1' and 'Tomaticat Giallo' ('TG') and an interspecific hybrid between $C$. frutescens $\mathrm{L}$. and $C$. chinense Jacq. Androgenic responsiveness in anther culture was also tested for the DH line AT6, derived from the anther culture of the ('ATZ1' $\times$ 'TG') $F_{1}$ hybrid. This line was included in the research material to serve as a genetically uniform control in comparison to the androgenic responsiveness of the analysed hybrid $\mathrm{F}_{2}$ generations. A detailed molecular and morphological assessment of the AT6 DH line as well as its parental form was previously presented by Olszewska et al. (2011). All of the materials were obtained from the collection maintained by the Department of Genetics and Plant Biotechnology at the University of Technology and Life Sciences in Bydgoszcz, Poland. Anther donor plants were cultivated in unheated plastic tunnels following the agro-technical practises typical for annual pepper.

Flower buds were sampled from 24 June through 3 August, individually from 20 plants of the hybrid ('ATZ1' $\times$ 'TG') $\mathrm{F}_{2}$ and AT6 line, and from $19(C$. frutescens $\times C$. chinense $) \mathrm{F}_{2}$ plants. The collected buds were rinsed with $70 \%$ ethanol, surface-sterilised by shaking in a $5 \%$ solution of calcium hypochlorite $\left(\mathrm{CaCl}_{2} \mathrm{O}_{2}\right)$ for 10 minutes, and subsequently rinsed three times with sterile distilled water. For each plant, 200 anthers were cultured following a modified procedure by Dumas de Vaulx et al. (1981) developed for $C$. annuum $\mathrm{L}$. The anthers were placed onto a $\mathrm{CP}$ induction medium, containing $0.01 \mathrm{mg} \mathrm{dm}^{-3} 2.4-$
D (2.4-dichlorophenoxyacetic acid); $0.01 \mathrm{mg}$ $\mathrm{dm}^{-3}$ kinetin and $5 \mathrm{mg} \mathrm{dm}{ }^{-3}$ of silver nitrate. For the first eight days, the anthers were incubated in the dark, at $35^{\circ} \mathrm{C}$. Afterwards, the culture was continually exposed to a 12 -hour photoperiod, and to a temperature of $25^{\circ} \mathrm{C}$. After 14 days, the anthers were transferred onto the $\mathrm{R} 1$ regeneration medium, supplemented with $0.1 \mathrm{mg} \mathrm{dm}{ }^{-3}$ of kinetin. The emerging embryos were subsequently transferred onto a V3 medium without growth regulators. To solidify all the media, $3 \mathrm{~g} \mathrm{dm}^{-3}$ of Gelrite was used. The regenerated plants were acclimatised in the greenhouse.

All of the observations during the experiment were made in the course of four months. For the genotypes evaluated, the number and percentage of obtained embryos against the total number of anthers placed onto the $\mathrm{CP}$ medium were determined. Considering the low level of contamination observed at the different stages of the experiment, the effectiveness of androgenesis was calculated only for those anthers that had not been contaminated during the culture.

The ploidy level of the regenerates was defined using a Partec CCA flow cytometer (Münster, Germany), equipped with a HBO-100W high pressure mercury lamp. The plant material for cytometric analysis was prepared according to Galbraith et al. (1983). Young leaves of C. annuum L. diploid annual pepper $(2 n=2 x=24)$ were used as the external standard. The results were presented in the form of histograms and analysed using Partec DPAC V.2.2 software.

\section{RESULTS AND DISCUSSION}

To define the relationship between plant genotype and the effectiveness of androgenesis, the individual plant reactions of the C. annuum ('ATZ1' $\times$ 'TG') $\mathrm{F}_{2}$ hybrid, interspecific hybrid (C. frutescens $\times$ C. chinense) $\mathrm{F}_{2}$ and $\mathrm{DH}$ line AT6 were analysed (Tabs 1-3). A clear variation in the effectiveness of androgenesis was found among the three tested genotypes. The highest efficiency of the process was noted for the plants of the $F_{2}$ hybrid between breeding lines of $C$. annuum. In anther cultures of this hybrid, a total number of 141 embryos were produced, and the average effectiveness of androgenesis accounted for $3.53 \%$. As for DH line AT6, an androgenic response accounting for $0.83 \%$ was observed, while androgenesis effectiveness reached only $0.24 \%$ for the interspecific hybrid $(C$. frutescens $\times C$. chinense) $\mathrm{F}_{2}$. 
The results of the present research confirm previous reports demonstrating that the higher efficiency of in vitro androgenesis is usually observed for breeding forms of C. annuum (Özkum Çıner and Tipirdamaz 2002, Buyukalaca et al. 2004). Individuals of the $\mathrm{F}_{2}$ generations of the $C$. annuum hybrid, as well as the AT6 plants, were characterised by medium-sized, bell or round shaped fruits, which are considered to be characteristic for highly androgenic-responsive pepper genotypes (Mityko et al. 1995). The effectiveness of androgenesis for other Capsicum species and interspecific hybrids is usually considerably lower (Rodeva et al. 2004, Niklas-Nowak et al. 2007, Niklas-Nowak and Nowaczyk 2009, Nowaczyk et al. 2009a), which was also proven in the presented experiment. According to the literature, cultures of isolated microspores are very often used as an alternative way of obtaining haploid plants. However, the effectiveness of pepper microspore culture protocols available up to date has never been comparable to the efficiency of Capsicum anther cultures (Ferrie and Caswell 2011, Irikowa et al. 2011).
Additionally, a clear variation in the individual response was observed among the analysed plants of all three tested pepper forms. The highest effectiveness of androgenesis (16.5\%) was reported for one plant of ('ATZ1' $\times$ 'TG') $\mathrm{F}_{2}$ (Tab. 1). The anthers of four other plants of this hybrid produced embryos at a frequency ranging from 6 to $7.5 \%$. As for the other 14 plants, the effectiveness of androgenesis ranged from 0.5 to $3.5 \%$, and no embryo development was noted for only a single plant. A lower androgenic response was observed for the plants of anther-derived line AT6 and interspecific hybrid $(C$. frutescens $\times C$. chinense $) \mathrm{F}_{2}$. The anthers isolated from flower buds of 13 plants of the AT6 line produced embryos at a frequency ranging from 0.5 to $3 \%$, while the other seven plants did not respond positively to the applied in vitro culture conditions (Tab. 3). On the other hand, only six out of the 19 plants evaluated for (C. frutescens $\times C$. chinense $) \mathrm{F}_{2}$ showed a positive androgenic reaction (Tab. 2). The effectiveness of androgenesis for this hybrid ranged from 0.5 to $2 \%$.

Table 1. Effectiveness of androgenesis and ploidy level of the regenerates obtained in anther cultures of the C. annuum ('ATZ1' × 'TG')F $F_{2}$ hybrid

\begin{tabular}{|c|c|c|c|c|c|c|c|c|}
\hline \multirow{3}{*}{$\begin{array}{l}\text { Plant } \\
\text { No.* }\end{array}$} & \multirow{2}{*}{\multicolumn{2}{|c|}{ Obtained embryos }} & \multicolumn{6}{|c|}{ Obtained plants } \\
\hline & & & \multicolumn{2}{|c|}{ Haploids } & \multicolumn{2}{|c|}{ Diploids } & \multicolumn{2}{|c|}{ Mixoploids } \\
\hline & Number & $\%$ & Number & $\%$ & Number & $\%$ & Number & $\%$ \\
\hline 1 & 15 & 7.5 & 3 & 1.5 & 3 & 1.5 & 1 & 0.5 \\
\hline 2 & 6 & 3 & 2 & 1.0 & 2 & 1.0 & - & - \\
\hline 3 & 6 & 3 & 1 & 0.5 & - & - & - & - \\
\hline 4 & 0 & 0 & - & - & - & - & - & - \\
\hline 5 & 33 & 16.5 & 5 & 2.5 & 8 & 4.0 & - & - \\
\hline 6 & 5 & 2.5 & 1 & 0.5 & - & - & - & - \\
\hline 7 & 1 & 0.5 & - & - & - & - & - & - \\
\hline 8 & 13 & 6.5 & 1 & 0.5 & 2 & 1.0 & - & - \\
\hline 9 & 15 & 7.5 & 1 & 0.5 & 1 & 0.5 & - & - \\
\hline 10 & 3 & 1.5 & 1 & 0.5 & - & - & - & - \\
\hline 11 & 3 & 1.5 & - & - & - & - & - & - \\
\hline 12 & 4 & 2.0 & 2 & 1.0 & 1 & 0.5 & - & - \\
\hline 13 & 7 & 3.5 & 2 & 1.0 & 4 & 2.0 & - & - \\
\hline 14 & 1 & 0.5 & - & - & - & - & - & - \\
\hline 15 & 12 & 6.0 & 1 & 0.5 & 1 & 0.5 & - & - \\
\hline 16 & 4 & 2.0 & - & - & - & - & - & - \\
\hline 17 & 2 & 1.0 & 1 & 0.5 & 1 & 0.5 & - & - \\
\hline 18 & 4 & 2.0 & - & - & - & - & - & - \\
\hline 19 & 5 & 2.5 & 1 & 0.5 & - & - & - & - \\
\hline 20 & 2 & 1.0 & - & - & - & - & - & - \\
\hline Total & 141 & 3.53 & 22 & 0.55 & 23 & 0.58 & 1 & 0.025 \\
\hline
\end{tabular}

*All of the observations were made using 200 anthers for each of the analysed plants 
About one third of a total of 183 embryos produced developed into plants of the right morphological structure, which were acclimatised under greenhouse conditions. In the anther cultures of 20 plants of ('ATZ1' $\times$ 'TG') $\mathrm{F}_{2}$, a total of 141 embryos were obtained, from which 46 (32.6\%) developed consequently into mature plants. For the AT6 line, 33 embryos gave rise to 13 plants (39.4\%), while for hybrid (C. frutescens $\times C$. chinense) $\mathrm{F}_{2}$, nine embryos were produced, five of which regenerated into plants $(55.5 \%)$. The present experiment recorded higher values of embryo regeneration as compared to those reported by Supena et al. (2006) and Nowaczyk and Kisiała (2006) for C. annuиm, as well as by Niklas-Nowak et al. (2007) for hybrid forms.

Plants developing in in vitro anther cultures are most often haploids or diploids; forms of a higher number of chromosomes appear only sporadically. The cytometric analysis, which covered 63 regenerates, showed the presence of both haploid (32 plants) and diploid forms (31 plants). A single mixoploid plant was reported only in the case of the hybrid ('ATZ1' $\times$ 'TG') $F_{2}$. The literature on the ploidy level of androgenic regenerates suggests that diploid plants can be produced in both anther and isolated microspore cultures of pepper and are most often the result of spontaneous doubling of the number of chromosomes at the early stages of haploid embryo development (Dumas de Vaulx et al. 1981, Mityko et al. 1995, Gyulai et al. 2000, Supena et al. 2006, Lantos et al. 2012). Depending on the genotype, spontaneous diploidisation of microspore-derived pepper regenerates has been observed with a frequency ranging from 13 to $51 \%$ (Supena et al. 2006, Lantos et al. 2012), while anther cultures resulted in up to $65 \%$ of spontaneous diploid plants (Mityko et al. 1995, Gyulai et al. 2000). We conclude that the spontaneous diploidisation of almost half of the young haploid embryos also occurred in the presented study. As it was visually observed, all the obtained androgenic regenerates formed inside of the anther, and at the early stages of development both haploids and diploids were characterised by a similar morphological appearance. Following the method presented earlier (Olszewska et al. 2011), biometrical assessment will be performed in the subsequent generations of the diploid regenerates to additionally prove their morphological homogeneity and microspore origin.

According to many researchers, donor plant genotype is the essential factor determining the effectiveness of androgenesis. A variation between
Table 2. Effectiveness of androgenesis and ploidy level of the regenerates obtained in anther cultures of the $(C$. frutescens $\times C$. chinense $\mathrm{F}_{2}$ hybrid

\begin{tabular}{lcccccc}
\hline \multirow{2}{*}{$\begin{array}{l}\text { Plant } \\
\text { No.* }\end{array}$} & \multicolumn{2}{c}{$\begin{array}{c}\text { Obtained } \\
\text { embryos }\end{array}$} & \multicolumn{4}{c}{ Obtained plants } \\
\cline { 4 - 7 } & Number & $\%$ & Number & $\%$ & Number & $\%$ \\
\hline 1 & 4 & 2.0 & 1 & 0.5 & 1 & 0.5 \\
2 & 1 & 0.5 & 1 & 0.5 & 1 & 0.5 \\
3 & 1 & 0.5 & - & - & - & - \\
4 & 1 & 0.5 & - & - & - & - \\
5 & 1 & 0.5 & 1 & 0.5 & 1 & 0.5 \\
6 & 1 & 0.5 & - & - & - & - \\
$7-19$ & 0 & 0 & - & - & - & - \\
\hline Total & 9 & 0.24 & 3 & 0.08 & 2 & 0.05 \\
\hline
\end{tabular}

*All of the observations were made using 200 anthers for each of the analysed plants

Table 3. Effectiveness of androgenesis and ploidy level of the regenerants obtained in anther cultures of AT6 DH line

\begin{tabular}{lcccccc}
\hline \multirow{2}{*}{$\begin{array}{l}\text { Plant } \\
\text { No. }\end{array}$} & \multicolumn{2}{c}{$\begin{array}{l}\text { Obtained } \\
\text { embryos }\end{array}$} & \multicolumn{5}{c}{ Haploids } & \multicolumn{2}{c}{ Diploids } \\
\cline { 4 - 7 } & Number & $\%$ & Number & $\%$ & Number & $\%$ \\
\hline 1 & 3 & 1.5 & - & - & - & - \\
2 & 1 & 0.5 & - & - & - & - \\
3 & 5 & 2.5 & 3 & 1.5 & 1 & 0.5 \\
4 & 5 & 2.5 & 1 & 0.5 & 2 & 1.0 \\
5 & 1 & 0.5 & - & - & - & - \\
6 & 1 & 0.5 & - & - & - & - \\
7 & 6 & 3.0 & - & - & - & - \\
8 & 1 & 0.5 & - & - & - & - \\
9 & 1 & 0.5 & - & - & 1 & 0.5 \\
10 & 3 & 1.5 & - & - & 1 & 0.5 \\
11 & 2 & 1.0 & 1 & 0.5 & - & - \\
12 & 1 & 0.5 & - & - & - & - \\
13 & 3 & 1.5 & 2 & 1.0 & 1 & 0.5 \\
$14-20$ & 0 & 0 & - & - & - & - \\
\hline Total & 33 & 0.83 & 7 & 0.18 & 6 & 0.15 \\
\hline
\end{tabular}

*All the observation were made for 200 anthers for each of the analysed plants

genotypes has been demonstrated for many agricultural and horticultural plants, including the species representing Capsicum genus (Rodeva et al. 2004, Nowaczyk et al. 2006, Lantos et al. 2012). The research shows that genetic differences in androgenic response can occur not only between various species, cultivars, and hybrid forms but also between individual plants of a single cultivar (Kristainsen and Anders 1993, Irikova and Rodeva 
2004, Nowaczyk et al. 2009b). We conclude that the differences detected in our experiment between individual plants of homozygous $\mathrm{DH}$ line AT6 might be the effect of a physiological variability characteristic for in vitro plant cultures. Additionally, they can also reflect some variation in the developmental stages of microspores in the anthers exposed to culture conditions. The results presented here also clearly confirm the variation in individual plant reaction of the two evaluated $\mathrm{F}_{2}$ hybrid generations, as well as the $\mathrm{DH}$ line. The highest effectiveness of androgenesis was recorded among ('ATZ1' $\times$ 'TG') $F_{2}$ hybrid plants. Anthers isolated from the plants of the androgenic line AT6 showed a slightly lower response, while the interspecific hybrid (C. frutescens $\times C$. chinense) $\mathrm{F}_{2}$ plants produced significantly fewer androgenic embryos.

\section{CONCLUSIONS}

1. In the presented work, high differences in androgenic response of the individual plants of the tested genotypes were observed, which confirms that donor plant genotype is the essential factor determining the effectiveness of androgenesis in pepper anther cultures.

2. For the C. annuum ('ATZ1' $\times$ ' $\mathrm{TG}^{\prime}$ ') $\mathrm{F}_{2}$ hybrid and the DH line AT6, an androgenic response was observed for most of the plants tested, whereas in the anther cultures of interspecific hybrid (C. frutescens $\times C$. chinense $) \mathrm{F}_{2}$, androgenic embryos were only produced for six out of the 19 analysed plants.

\section{REFERENCES}

Buyukalaca S., Comlekcioglu N., Abak K., Ekbic E., KILIC N., 2004. Effects of silver nitrate and donor plant growing conditions on production of pepper (Capsicum annuum L.) haploid embryos via anther culture. Eur. J. Hort. Sci. 69 (5): 206-209.

CHоo T.M., 1981. Doubled haploid for studying the inheritance of quantitative characters. Genetics 99: 525-540.

Dumas de Vaulx R., Chambonnet D., Pochard E., 1981. Culture in vitro d'anthéres de piment (Capsicum annuum L.) amélioration des taux d'obtention de plantes chez différents génotypes par des traitements á $+35^{\circ} \mathrm{C}$. Agronomie 1: 859-864.

Ercan N., Sensoy F.A., Sensoy A.S., 2006. Influence of growing season and donor plant age on anther culture response of some pepper cultivars (Capsicum annuиm L.). Sci. Hortic. 110: 16-20.
Ferrie A.M.R., CASWELl K.L., 2011. Isolated microspore culture techniques and recent progress for haploid and doubled haploid plant production. Plant Cell Tiss. Organ Cult. 104: 301-309.

Galbraith D.W., Harkins K.R., Maddox J.M., Ayres N.M., Sharma D. P., Firoozabady E., 1983. Rapid flow cytometry analysis of the cell cycle in intact plant tissues. Science 220: 1049-1051.

Gyulai G., Gemesne J.A., Sagi Z.S., Venczel G., Pinter P., Kristof Z., Torjek O., Heszky I., Botka S., Kiss J., ZАтүко L., 2000. Doubled haploid development and PCR-analysis of $\mathrm{F}_{1}$ hybrid derived $\mathrm{DH}-\mathrm{R}_{2}$ paprika (Capsicum annuum L.) lines. J. Plant Physiol. 156: 168-174.

Irikowa T., Grozeva S., Rodeva V., 2011. Anther culture in pepper (Capsicum annuum L.) in vitro. Acta Physiol. Plant. 33: 1559-1570.

IRIKova T., Rodeva V., 2004. Anther culture of pepper (Capsicum annuum L.): comparative study on effect of the genotype. Biotechnol. \& Biotechnol. Eq. 18 (3): 34-38.

Kim M., Jang I.C., Kim J.A., Park E.J., Yoon M., Lee Y., 2008. Embryogenesis and plant regeneration of hot pepper (Capsicum annuum L.) through isolated microspore culture. Plant Cell Rep. 27(3): 425-434.

Kristiansen K., Andersen S.B., 1993. Effects of donor plant, temperature, photoperiod and age on anther culture response of Capsicum annuum L. Euphytica 67: 105-109.

Lantos C., Juhasz A.G., Vagi P., Mihaly R., Kristof Z., PAUK J., 2012. Androgenesis induction in microspore culture of sweet pepper (Capsicum annuum L.). Plant Biotechnol. Rep. 6: 123-132.

Mityko J., Andrasfalvy A., Csillery G., Fari M., 1995. Anther-culture response in different genotypes and $\mathrm{F}_{1}$ hybrids of pepper (Capsicum annuum L.). Plant Breeding 114: 78-80.

Niklas-Nowak A., Jędrzejczyk J., Nowaczyk P., 2007. Anther culture of interspecific hybrids from Capsicum genus. In: Spontaneous and induced variation for the genetic improvement of horticultural crops. Nowaczyk P. (ed), University of Technology and Life Science Press, Bydgoszcz.

Niklas-Nowak A., Nowaczyk P., 2009. The effect of temperature on the effectiveness of androgenesis within Capsicum genus. In: Genetyka i Genomika w doskonaleniu roślin uprawnych. Naganowska B., Kachlicki P., Krajewski P. (eds), Instytut Genetyki Roślin PAN, Poznan.

NowaczyK P, Kisiąa A., 2006. Effect of selected factors on the effectiveness of Capsicum annuum L. anther culture. J. Appl. Genet. 47(2): 113-117.

Nowaczyk P, Kisiala A., Olszewska D., 2006. Induced androgenesis of Capsicum frutescens L. Acta Physiol. Plant. 28(1): 35-39.

Nowaczyk P., Nowaczyk L., Olszewska D., Krupska A., 2009a. Androgenic response of genotypes selected 
from Capsicum annuum L. $\times$ C. chinense Jacq. hybrids. Acta Physiol. Plant. 31: 877-879.

Nowaczyk P., Olszewska D., Kisiala A., 2009 b. Individual reaction of Capsicum $\mathrm{F}_{2}$ hybrid genotypes in anther cultures. Euphytica 168: 225-233. DOI 10.1007/s10681-009-9909-4.

Rodeva V.N., Irikova T.P., Todorova V.J., 2004. Anther culture of pepper (Capsicum annuum L.): comparative study on effect of the genotype. Biotechnol. \& Biotechnol. Eq. 18(3): 34-38.

Olszewska D., Kisiala A., Nowaczyk P., 2011. The assessment of doubled haploid lines obtained in pepper (Capsicum annuum L.) anther culture. Folia Hort. 23(2): 93-99.

ÖZkum ÇInER D., Tipirdamaz R., 2002. The effects of cold treatment and charcoal on the in vitro androgenesis of pepper (Capsicum annuum L.) Turk. J. Bot. 26: 131139.

Supena E.D.J., Suharsono S., Jacobsen J., Custers J.B.M., 2006. Successful development of a shedmicrospore culture protocol for doubled haploid production in Indonesian hot pepper (Capsicum annuum L.). Plant Cell Rep. 25(1): 1-10.

\section{REAKCJA OSOBNICZA W KULTURACH PYLNIKÓW WYBRANYCH GENOTYPÓW PAPRYKI (CAPSICUM SPP.)}

Streszczenie: Jednym z zasadniczych czynników decydujących o skuteczności androgenezy u papryki jest genotyp roślin donorowych. Materiał wyjściowy do indukcji zarodków stanowią naj- częściej formy mieszańcowe, ponieważ im wyższy stopień heterozygotyczności, tym większe szanse uzyskania form o oryginalnym genotypie. Celem przeprowadzonych badań była ocena reakcji osobniczej na warunki indukowanej androgenezy w kulturach pylników mieszańca między uprawnymi liniami gatunku C. annuum ('ATZ1' $\times$ ' $\left.\mathrm{TG}^{\prime}\right) \mathrm{F}_{2}$, mieszańca międzygatunkowego (C. frutescens $\times$ C. chinense $) \mathrm{F}_{2}$ oraz linii $\mathrm{DH}$ AT6, wyprowadzonej z mieszańca ('ATZ1' $\times$ 'TG') $\mathrm{F}_{1}$. Dla wszystkich ocenianych genotypów oznaczono liczbę i procentowy udział otrzymanych zarodków w stosunku do całkowitej liczby wyłożonych pylników (efektywność androgenezy), indywidualnie dla każdej z roślin donorowych. W przypadku mieszańca ('ATZ1' × 'TG')F $F_{2}$ pylniki 19 z 20 ocenianych roślin wytwarzały zarodki $\mathrm{z}$ częstotliwością od 0,5 do $16,5 \%$. Pylniki linii DH AT6 formowały znacznie mniej zarodków. Pozytywną reakcję odnotowano tutaj dla 13 z 20 roślin, przy czym efektywność androgenezy nie przekroczyła 3\%. Najniższą odpowiedź androgeniczną odnotowano dla mieszańca $(C$. frutescens $\times C$. chinense $) \mathrm{F}_{2}$, gdzie indukcję zarodków zaobserwowano jedynie dla 5 z 19 roślin, a efektywność androgenezy nie przekroczyła $2 \%$. Analiza cytometryczna wykazała obecność roślin haploidalnych i diploidalnych wśród regenerantów wszystkich ocenianych genotypów.

Received July 18, 2012; accepted September 26, 2012 